\title{
HUMAN RESOURCE ASPECT OF AGRICULTURAL ECONOMY - CHALLENGES OF DEMOGRAPHIC CHANGE
}

\author{
Alexandra Rajczi ${ }^{1}$ - Péter Vörös ${ }^{2}$ - Krisztina Dajnoki ${ }^{3}$ \\ ${ }^{1}$ University of Kaposvár Doctoral School of Management and Organizational Science \\ e-mail: rajczi.alexandra@ke.hu \\ ${ }^{2}$ University of Kaposvár Direction of Economic and Engineering \\ e-mail: voros.peter@ke.hu \\ ${ }^{3}$ University of Debrecen Faculty of Economics And Business Institute of Management and Organization Sciences \\ e-mail: krisztina.dajnoki@econ.unideb.hu
}

\begin{abstract}
Over the past decades, the agrarian policy has tried to contribute to the catching-up of the rural areas with varying dynamism and aid scheme. However, its result is significantly below expectations. Nowadays, the age composition of the population living in rural areas reveals an unfavourable picture; the rate of the elderly, deprived persons and people being inactive from the aspect of employment is high and it is also combined with the low educational levels. The young generations and intellectuals leave the rural areas and, consequently, the rate of the active population continues to grow narrow as well as the proportion of young and skilled employees decreases. As a consequence of changes in the past decades, the rate of agricultural employment has not led to an intensive change but a failing change in extensive direction which lays off jobs. Nowadays, this process also determines the Hungarian rural society. In the sector, the need for employment diminishes as a result of the development in technology and due to the expansion of services sector. The purpose of our study is to present and analyse the human resources of our country's agriculture by skill level and age group and compare it with the needs of companies, by doing this we try to compare supply and demand. In details, based on secondary data source, we investigate the agricultural labour force and try to confront it with the advertisements of job search portals (three of our job search portals based on our predefined criteria), by which we achieve a current picture of the agricultural human resource circumstances.
\end{abstract}

Keywords: agriculture, rate of employment, ageing society, generational change, labour force.

(JEL Code: J 43)

\section{INTRODUCTION}

Our country's agricultural economy has an age-old history, our natural conditions are more favourable than average so, as a consequence, it is ensured that a crop outcome in appropriate quality and optimum quantity can be achieved. The nonpareil agro-ecological potential of the Carpathian Basin is the major natural treasure for Hungary. Our country's natural and climatic conditions are excellently capable of carrying out agricultural activities. The current troubles and problems of the Hungarian agricultural sector are significantly rooted in the agrarian policy after the change of regime. During this period, the economic rationality has been overshadowed. As a part of the social and economic change of regime, transformation of ownership and operating structures determined the performance of agriculture and the utilization of labour force. Agriculture of the 90s was characterized by a decreasing employment and an increasing unemployment. Agriculture plays a decisive role in the rural employment as well as it provides and maintains a livelihood for the rural population. Due to the progresses of restitution and privatization and after abolishing the structure of large-scale industry, the employment has been reduced to its fraction. The change of regime has clearly stricken the largest blow against the rate of employment by laying off more than 1.6 million jobs countrywide. Among the sectors, labour force in the agriculture has been drastically reduced. After the liquidation of large establishments, the employees massively become unemployed which has led to an increased depopulation of rural areas (TAKÁCS, 2010). Currently, the employment level of rural areas plays a key role in the European Union thus in our country as well. Both the EU's agrarian policy and the government policies make numerous efforts to contribute to the recovery in the rate of rural employment. 


\section{Position of employment of agricultural sector in the national economy}

The performance of our agrarian economy has diminished over the past decades. The rural towns and villages have grown poor as well as the rate of unemployment has intensified drastically (SZABÓ, 2010). BOJNEC and FERTŐ (2009) studied the competitiveness of foreign countries in five European countries in their study. The authors have shown that competitiveness in the five Central European countries between 1995 and 2005 is determined by natural factors and human resources supply. Based on the data of Table 1, it can be stated that, while the performance of agriculture has contributed $7.1 \%$ to the production of GDP and $8.4 \%$ to the Gross Value Added in the mid-1990s, these values indicate only $3.7 \%$ and $4.4 \%$ by 2014 . The agricultural investment was $2.9 \%$ in 1995, it increased to $4.3 \%$ in the year of our accession to the European Union and to $6.1 \%$ in 2014 which can be significantly attributed to the incentives ensured by the enhanced subsidy system. The agricultural investment has strengthened by 1.8 percentage points during 10 years after our accession of 2004.

Table 1: Role of agriculture in the national economy (\%)

\begin{tabular}{|l|c|c|c|c|}
\hline Year & $\begin{array}{c}\text { Gross } \\
\text { Domestic } \\
\text { Product } \\
\text { (GDP) }\end{array}$ & $\begin{array}{c}\text { Gross Value } \\
\text { Added }\end{array}$ & Investment & Employment \\
\hline 1995 & 7.1 & 8.4 & 2.9 & 8 \\
\hline 2000 & 4.9 & 5.8 & 4.7 & 6.6 \\
\hline 2004 & 4.3 & 5.1 & 4.3 & 5.3 \\
\hline 2010 & 3 & 3.6 & 4.8 & 4.6 \\
\hline 2011 & 3.9 & 4.7 & 5.6 & 4.9 \\
\hline 2012 & 3.8 & 4.5 & 5.8 & 5 \\
\hline 2013 & 3.7 & 4.4 & 5.9 & 4.7 \\
\hline 2014 & 3.7 & 4.4 & 6.1 & 4.6 \\
\hline \multicolumn{5}{|c|}{ Source: own editing based on data of KSH (2015) }
\end{tabular}

The role of agriculture was decisive in the employment until the change of regime, mainly in the rural regions. Its proportion had been $8 \%$ in the employment in the mid-1990s but this value regressed to $4.6 \%$ by 2014 . Nowadays, an intensifying expansion of the services sector is increasingly determinative in our country, similarly to the international trends. The sector basically requiring labour has generated a decrease in the employment by applying modern technologies and tightening the diversification of production structure. Over the past decades, the higher income available in other sectors of the national economy and the more favourable living conditions have enhanced the outflow of labour force from the sector. The decrease in the employment has largely reorganized the structure of national economy sectors (BÍRÓ et al, 2012). This turnaround has led to shrinkage in utilization of human resource of productive sectors and an expansion of the services sector. In Poland, the rural population accounts for $39 \%$ of the country's population. Polish agriculture remained very fragmented. Agriculture accounts for $3.4 \%$ of the country's GDP and $12-14 \%$ of the total employed. Despite the fragmented ownership structure based on family farms, Polish agriculture showed better results in the decade following EU accession than in Hungary (POTORI et al, 2014). In Figure 1, we can see the trend in number of employees in terms of the national economy as a whole, the agricultural sector and food industry from the year of the regime change to 2014.

Figure 1: Number of employees in the national economy, agriculture and food industry

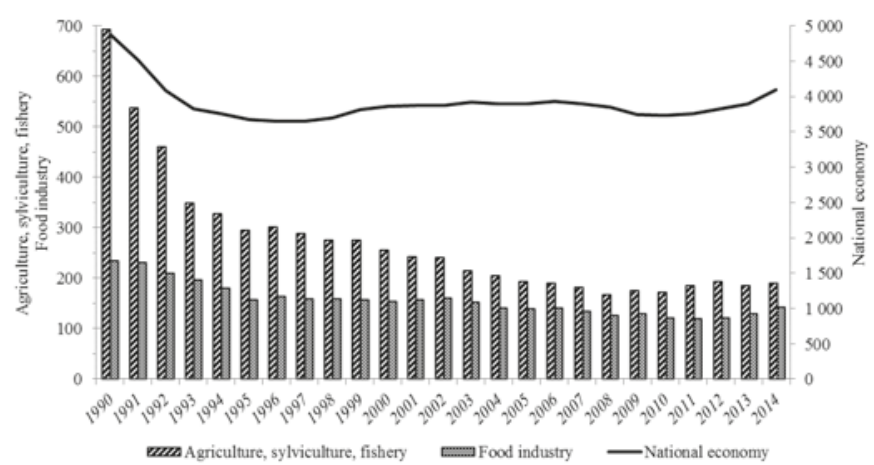

Source: own editing based on data of KSH (2015)

Employment of both the national economy and the agricultural sector show decreasing trends until the mid1990s but this regression has a lower measure in the national economy. In the first decade of 2000s, a slight growth can be experienced in number of employees of the national economy while the decline of agricultural sector deepened further. In 2010, the decreasing trend in agricultural sector took a turn and a slight growth was experienced, in parallel, an enlargement in the employment can also be observed in the national economy. In parallel with the development of technology, a decrease in the human resource utilization can be predicted in the agrarian economy (POPP, 2014).

\section{Role of self-employment in the agriculture}

Nowadays, the European Union's agriculture is increasingly driven towards the dual structure. On one side, there are goods producing professional large plants which produce a significant part of commodities on a considerable proportion of the territory. On the contrary, there are such small farms which are typically disadvantageous from economic or natural aspects and they mostly produce for self-sufficiency and possibly for local markets in addition (VARGA, 2014). The decline in number of employees in the agricultural sector can be justified by the transformation in production structure and the expansion of individual farming (POTORI and UDOVECZ, 2004). There are structural differences between family farms in the European Union. One of the advantages of family farms is flexibility, based on low transaction costs. The future of family farming is closely related to the difference between agricultural and urban income. According to the authors, family farms will play an 
important role in the structure of agriculture in the European Union (DAVIDOVA and THOMPSON, 2014). The individual farmers carry out their farming in this form partly due to the fact that the chance for finding paid employment is low, the opportunities of becoming self-employed are attractive and it implies relative benefits as well as it is incentive to take over the family pattern (SCHARLE, 2000). Figure 2 illustrates the age composition of number of individual farmers.

Figure 2: Number of farmers in individual farms, by age group

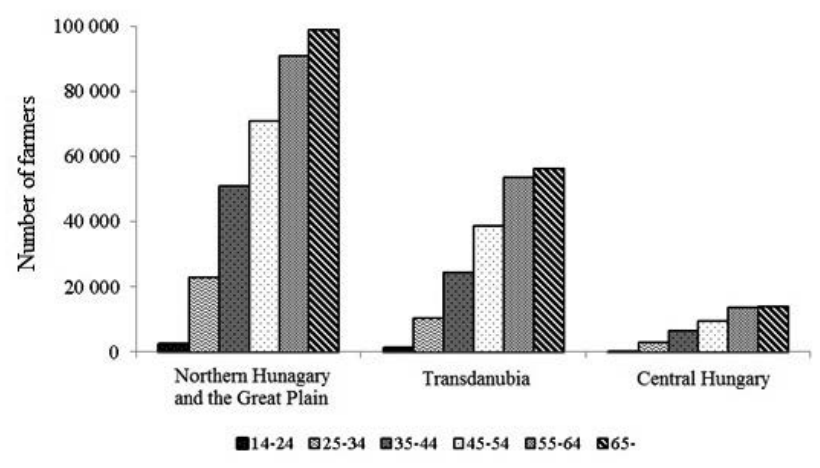

Source: own editing based on data of KSH (2015)

Based on the results, it can be stated the number of farmers are the highest in the Great Plain region considering the individual farms, however, it can be observed that people over 65 are represented in the highest number within the region. Among the age-groups, increasingly young age-groups take part in the farming in lower and lower number. The rate of young age-group between 14 and 24 years can be considered extremely low. In case of the Transdanubia region which has also favourable natural conditions, the older generation is also determinative considering the age composition of farmers. Central Hungary has farmers in low number in terms of individual farms, due to its central location. By analysing the data, we can see the age composition of people farming individually indicates an unfavourable trend in different regions of our country: the rate of older people is high and the rate of younger people is extremely low so it would be necessary to incite and motivate the younger generations for the opportunities provided by the agriculture. However, the agricultural labour force management is influenced by such factors which do not affect any other sectors; one of the most environmental factors is the geographical fixity. The location of a plant largely determines the supply-demand relation of labour force (BUZÁS et al, 2000). Moreover, many organizations are using more and more temporary workers today (GRIFFIN, 2013), and this is also a specification of the agricultural sector.

\section{MATERIALS AND METHODS}

To carry out the study, we conducted desk research/ secondary analysis based on domestic literature sources. According to BABBIE (2007) "Secondary analysis is a form of research in which the data collected and processed by one researcher are reanalyzed-often for a different purpose-by another." The study analyzes domestic agricultural enterprises based on the data collected by the Central Statistical Office. The analysis works with statistically closed 2015 public data. In the interest of better illustration, we have prepared diagrams and tables of the data collected by the Central Statistical Office using the Microsoft Excel program. As a more empirical method, we also investigated three of our job search portals based on our predefined criteria. We have collected the expectations for four jobs to be filled in and summarized in a table, which had relevance with the agricultural sector. Based on our research and the secondary data examined and our own research, conclusions and recommendations were formulated.

\section{Quality of human resource staff of the agriculture}

Challenges of today appear not only in political and economic areas but the demographical processes and their consequences play a key role. The ageing population, the incresingly higher levels of education as well as the change in image of the traditional family model can be ranged among the trends influencing those human resource activites which can be observed in composition of world population (BOKOR et al, 2010). However, contrary to the national economic trend, the agriculture is not determined by the higher level of education but the qualification and the lack of appropriate quality.

Service providing is currently the most dinamically developing sector in the world economy. A considerable part of employees works in this sector in the developed countries. Due to this, the employment structure has changed in the developed industrialised countries. A large number of labour force has become needless as a consequence of technological developments in the traditional productive sectors, thus in the agriculture as well. By a higher level organization of processing, the production of products requires lower physical labour force, consequently, the tertiary sector has become a sector employing one of the biggest labour force in the developed countries. Due to the scientific results and technological developments, we are increasingly nearing towards the knowledge-based economy where the knowledge, skills and intelligence of human is determinative (BERDE, 2003) and the existence of those personal competences (e.g. motivation, persistence) is also determining which contribute to the achievment of goals and a successful working (GERGELY and NAGY, 2015). In Figure 4, the distribution of people having agricultural qualification can be seen by region and age-group. 
Figure 3: Distribution of persons with agricultural qualification, by age group

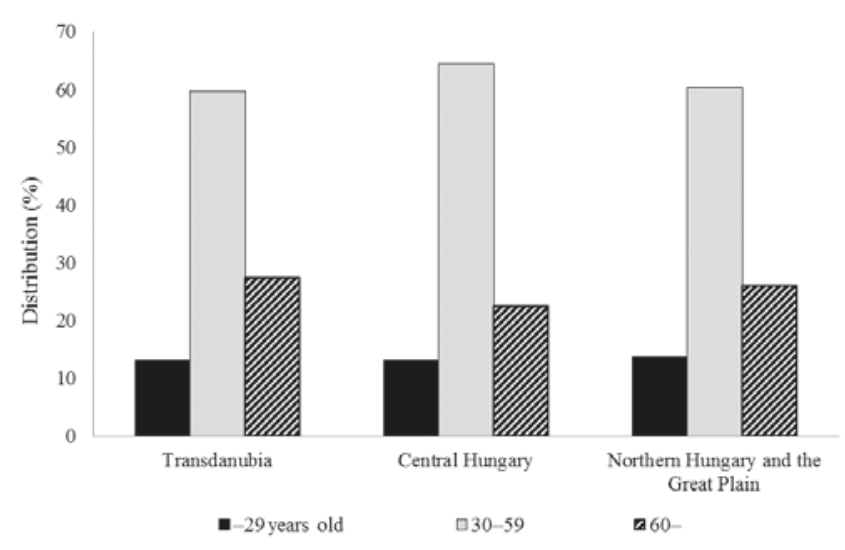

Source: own editing based on data of KSH (2015)

Based on the results, it can be stated that the rate of people having agricultural qualification is mainly composed of the 30 - 59 old age-group. It can also be stated that in all the three of the examined regions, the age group of over 60 is twice as the age of 29 years. It is deemed to highlight that only $13 \%$ of age-group under 29 have agricultural qualification. In the agricultural sector, a significant part of the labour force has only the needed diligence and the knowledge handed down from father to son so they find themselves among the longterm unemployed persons (MAGDA, 2011).

Next, the people having agricultural qualification will be analysed according to their highest educational level completed successfully (Figure 4).

\section{Figure 4: Distribution of persons with agricultural qualification, by their highest educational level completed successfully}

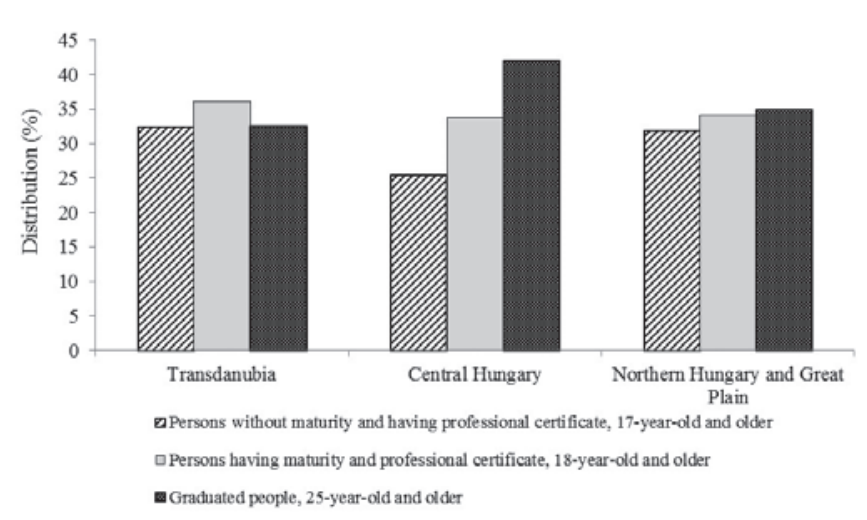

Source: own editing based on data of KSH (2015)

The share of highly educated people is the highest in the Central Hungarian region due to its central location and the capital; this fact is justified by the central jobs requiring higher intellectual work decisively. In Transdanubia, the share of people having professional qualification and no maturity and the share of highly educated persons are the same while the number of people having maturity and professional certificate simultaneously is higher. In the Northern Hungarian and Great Plain regions collectively, the stock of people achieving the education attainment is increasing in parallel with the rise in level of educational attainment.

In case of people having completed higher education, those civil society organizations can assist to stay in field and find a job where they can build the theoretical knowledge in practice, helping to succeed in the long term (SZABADOS and PIEROG, 2011).

By examining job search portals 'careerjet', 'agroinform' and 'profession', relatively few vacancies can be found where employees is wanted in agricultural sector in rural areas (Table 2).

Table 2: Main expectations and competences in agricultural job advertisements

\begin{tabular}{|l|l|l|l|}
\hline & $\begin{array}{l}\text { Job search } \\
\text { portal No. 1 }\end{array}$ & $\begin{array}{l}\text { Job search } \\
\text { portal No. 2 }\end{array}$ & $\begin{array}{l}\text { Job search portal } \\
\text { No. 3 }\end{array}$ \\
\hline $\begin{array}{l}\text { Machine } \\
\text { Operator }\end{array}$ & $\begin{array}{l}\text { Experience, } \\
\text { reliability }\end{array}$ & $\begin{array}{l}\text { Independence, } \\
\text { accuracy }\end{array}$ & - \\
\cline { 4 - 4 } Animal \\
Caretaker & $\begin{array}{l}\text { Reliability, } \\
\text { physical } \\
\text { capacity }\end{array}$ & $\begin{array}{l}\text { Reliability, } \\
\text { independence }\end{array}$ & $\begin{array}{l}\text { Secondary vocational } \\
\text { qualification, } \\
\text { experience, strong } \\
\text { physique }\end{array}$ \\
\hline Executive \\
Director & $\begin{array}{l}\text { Good mana- } \\
\text { gement skills, } \\
\text { reliability, } \\
\text { honesty, } \\
\text { experience }\end{array}$ & - & $\begin{array}{l}\text { Higher specialised } \\
\text { qualification, } \\
\text { knowledge of } \\
\text { foreign languages, } \\
\text { professional } \\
\text { experience }\end{array}$ \\
\hline Adviser & $\begin{array}{l}\text { Agrarian } \\
\text { qualification, } \\
\text { result-oriented } \\
\text { approach, } \\
\text { good } \\
\text { communication } \\
\text { skills, self- } \\
\text { confidence }\end{array}$ & - & \\
\hline
\end{tabular}

Source: own editing based on data of careerjet.hu, agroinform.com and profession.hu (2016)

In case of majority of advertisements placed by rural plants, practising an occupation is not subject to professional qualifications but rather the professional experience, accuracy, autonomy at work and reliability are highlighted. However, there are some job advertisements - managerial, consulting and other jobs requiring intellectual work decisively - where the existence of minimum secondary qualification is a must. In case of jobs like these ones, inter alia, the good communication skills, self-confidence, resoluteness and result-oriented approach also confer a benefit. 


\section{CONCLUSIONS}

The agrarian economy of our country provided the income for the people living in rural areas for a long time; both the agricultural sector and the food industry had a leading role during this period. The structure of agriculture was such that ensured the rural employment. Nowadays, number of agricultural employees can be considered to be extremely low due the privatisation procedures launched after the change of regime. This resulted in the development of an increasingly growing unemployment in the rural villages and towns, which has been consequently depopulated and this feature still determines the region now. And, in case of the existing employees, the lack of educational attainment and quality can be experienced. This circumstance means further difficulties since the agricultural sectors essentially need labour in addition to a higher level of technology. Considering the number of age composition employed in the agriculture, the older age-group is determining. Incitement of the younger age-group becomes justified, a generational change would be necessary in the agricultural sector. The results of the job seeks indicated that relatively few vacancies were found where employees were wanted in agricultural sector in rural areas, this may also led to the migration of the youth. Catching up the rural areas of Hungary and contributing to the growth are required to realize the sustainability in the future. Stopping the negative progresses experienced in rural areas being disadvantageous from aspects of demography, qualification and economy is requiring such a new and full rural development strategy which leads to that a competitive agrarian structure can evolve and an increase in number of employees become available as well.

\section{REFERENCES}

Agroinform (2016): Mezőgazdaság álláshirdetések. http:// www.agroinform.com/aprohirdetes/allas-1187/c1. Letöltés ideje: 2016.05.17.

Babbie, E. (2007): The Practice of Social Research. Thomson Wadsworth, Belmont.

Berde Cs. (2003): Menedzsment a mezőgazdaságban - Vezetési módszerek és sajátosságok. Szaktudás Kiadó Ház, Budapest.

Bertalan P., Geszti Sz., Pintér A. (2007): A globalizáció és a magyar mezőgazdaság versenyképessége. Közép- és KeletEurópa integrálódása az egységes európai térségbe, Székesfehérvár.

Bíró Sz., Hamza E., Molnár A., Rácz K., Székely E., Tóth K., Tóth O., Varga E. (2012): A mezőgazdasági foglalkoztatás bővítésének lehetőségei vidéki térségeinkben. Agrárgazdasági Kutató Intézet, Budapest.

Bojnec S., Fertő I. (2009): Determinants of agro-food trade competition of Central European Countries with the European Union. China Economic Review, 20 (2).

Bokor A., Szőts-Kováts K., Csillag S., Bácsi K., Szilas R. (2010): Emberi erőforrás menedzsment. Aula Kiadó Kft., Budapest.
Buzás Gy., Nemessályi Zs., Pfau E., Pupos T., Salamon L., Somogyi S., Szakál F., Székely Cs. (2000): Mezőgazdasági Üzemtan I. Mezőgazdasági Szaktudás Kiadó, Budapest.

Careerjet álláskeresô portál (2016): Mezőgazdaság, erdészet, halászat álláshirdetések. http://www.careerjet.hu/wkeres/ allasok?c=mezogazdasag -erdeszet-halaszat\&l=Magyar or sz\%C3\%A1g\&lid=125322\&b=101\&cid=12 Letöltés ideje: 2016.05.17.

Davidova S., Thomson, K. J. (2014): Family Farming in the Enlarged EU: Concepts, challenges and prospects. In 142nd Seminar, May 29-30, 2014, Budapest, Hungary. European Association of Agricultural Economists.

Gergely É., Nagy R. (2015): Gazdasági szakos hallgatók tanulási motivációjának és személyes kompetenciáinak vizsgálata. Közép-Európai Közlemények VIII. évfolyam:(4. szám, No.31.) pp. 197-205.

Griffin, R. (2013): Management. 11th Ed. Cengage Learning, Mason.

Központi Statisztikai Hivatal (2015): A mezőgazdaság szerepe a nemzetgazdaságban. http://www.ksh.hu/docs/hun/xftp/idoszaki/mezo/mezoszerepe15.pdf Letöltés ideje: 2016.05.02.

Központi Statisztikai Hivatal (2010): A gazdálkodók száma az egyéni gazdaságokban, korcsoportok szerint.

http://www.ksh.hu/docs/hun/stabla/amo/tablamo_2_7.html Letöltés ideje: 2016.05.08.

Központi Statisztikai Hivatal (2011): A mezőgazdasági képzéstől a pályaelhagyásig.

http://www.ksh.hu/docs/hun/xftp/idoszaki/pdf/mkepzes.xls Letöltés ideje: 2016.05.12.

Magda S., Bíró B. (2011): Mezőgazdaság - vidék - foglalkoztatás. Magyar Tudomány, 2011.8.

Popp J. (2014): Hatékonyság és foglalkoztatás a magyar mezőgazdaságban. Gazdálkodás, 58. évfolyam, 2014.2.

Potori N., Chmielinski P., Karwat-Wozniak B. (2014): A comparison of the agro-food sectors in Poland and Hungary from a macro perspective. Research Institute of Agricultural Economics, 2014, 9.

Potori N., Udovecz G. (2004): Az EU csatlakozás várható hatásai a magyar mezőgazdaságban. Agrárgazdasági Kutató Intézet, Budapest.

Profession (2016): Mezőgazdaság, környezet álláshirdetések. https://www.profession.hu/allasok/mezogazdasag-kornyezet/1,21 Letöltés ideje: 2016.05.17.

Scharle Á. (2000): Önfoglalkoztatás, munkanélküliség és családi kisvállalkozások Magyarországon. Közgazdasági Szemle, 47. évfolyam.

Szabados Gy. 0 Pierog A. (2011): Önkéntesség és a civilek. In: Szele Bálint (szerk.) Tehetséggondozási workshopok a Kodolányi János Főiskolán 3.. Székesfehérvár: Kodolányi János Főiskola (KJF), pp. 65-70.

Szabó Gy. (2010): Föld- és területrendezés. Nyugat-magyarországi Egyetem, Székesfehérvár.

Takács J. (2010): A mezőgazdaság és élelmiszeripar üzemi szerkezete. Szaktudás Kiadó, Budapest.

Varga É. (2014): Törpegazdaságok Magyarországon és az Európai Unió déli tagországaiban.

Gazdálkodás, 58. évfolyam,. 2014.2. 
